Journal of Maternal and Child Health (2019), 4(6): 474-485

https://doi.org/10.26911/thejmch.2019.04.06.08

\title{
Multilevel Analysis on Factors Associated with Occurrence Chronic Energy Deficiency among Pregnant Women
}

\author{
Nur Cahya Rachmawati'), Yulia Lanti Retno Dewi²), Vitri Widyaningsih²) \\ 1)Masters Program in Public Health, Universitas Sebelas Maret \\ 2)Faculty of Medicine, Universitas Sebelas Maret
}

\begin{abstract}
Background: One of the nutritional problems experienced by pregnant women is chronic energy deficiency (CED). Chronic energy deficiency is a condition in which women of childbearing age experience a lack of energy and protein intake and take place continuously resulting in health problems. This study aims to analyze chronic energy deficiency factors in pregnant women in Gunungkidul Regency.

Subjects and Method: This study implemented a case control design. It was conducted in 25 community health centers, Gunungkidul, Yogyakarta, from April to May 2019. A sample of 200 pregnant women was selected by fixed disease sampling. The dependent variable was chronic energy deficiency in pregnant women. The independent variables included food intake, education level, occupation, knowledge, family income, age, parity, utilization of antenatal care services (ANC), and food availability. The data were collected using the MUAC tape and questionnaire. The data were analyzed by a multilevel multiple logistic regression.

Results: The risk of protein energy deficiency decreased with high energy and protein intake $(\mathrm{b}=-$ 2.74; 95\% CI $=-7.74$ to $-1.28 ; \mathrm{p}=0.006)$, more education level than high school $(\mathrm{b}=-2.16$; $95 \% \mathrm{CI}$ $=-4.54$ up to $-0.22 ; \mathrm{p}=0.030)$, working mothers $(\mathrm{b}=-2.75 ; \mathrm{CI} 95 \%=-9.48$ to $-1.59 ; \mathrm{p}=0.006)$, sufficient knowledge $(\mathrm{b}=-2.32 ; \mathrm{CI} 95 \%=-6.27$ to $-0.52 ; \mathrm{p}=0.020)$, high family income $(\mathrm{b}=-2.38$; CI 95\% $=-6.27$ to $-0.60 ; \mathrm{p}=0.017)$, age $\geq 20$ years to 35 years $(\mathrm{b}=-2.17 ; 95 \% \mathrm{CI}=-5.16$ to $-0.26 ; \mathrm{p}$ $=0.030)$, parity $>2(\mathrm{~b}=-2.57$; CI $95 \%=-8.42$ to $-1.13 ; \mathrm{p}=0.010)$, using high ANC services $(\mathrm{b}=-$ 2.72; 95\% CI $=-9.20$ to $-1.49 ; \mathrm{p}=0.007)$, and food availability is fulfilled $(\mathrm{b}=-2.54$; CI $95 \%=-$ 7.63 to $-0.98 ; \mathrm{p}=0.011$ ). Public health centers had a large contextual influence on chronic energy shortages with an ICC of $51.25 \%$.

Conclusion: There is a significant influence between food intake, education level, occupation, knowledge, family income, age, parity, utilization of ANC services, and food availability for chronic energy shortages in pregnant women. The variations at the public health centers level show that there is a contextual influence on chronic energy shortages in pregnant women.
\end{abstract}

Keywords: chronic energy deficiency (CED), multilevel analysis, pregnant women

\section{Correspondence:}

Nur Cahya Rachmawati. Master's Program in Public Health, Universitas Sebelas Maret, Surakarta, Jl. Ir. Sutami 36A, Surakarta 57126, Central Java. Email: nurcahyarachmawatii@gmail.com. Mobile: +6287838992205.

\begin{tabular}{l}
\hline BACKGROUND \\
Nutritional problems are still a problem \\
that needs to be considered, one of them is \\
nutrition problems in pregnant women. \\
During the process pregnancy nutritional \\
needs will increase so that women will \\
easily experience nutritional problems. One \\
of the nutritional problems experienced by
\end{tabular}

pregnant women is chronic energy deficiency (Maryani et al., 2017). Chronic energy deficiency is a condition where women of childbearing age experience a lack of energy and protein intake and take place continuously resulting in health problems (Arisman, 2010). 
Chronic energy deficiency is caused by direct factors and indirect factors. The direct factor is the intake of food sources of energy and protein and infectious diseases. Indirect factors include age, parity, level of education, knowledge, occupation, family income, food expenditure, food availability and frequency of presence of ANC (Almatsier, 2009).

Consumption of food that is not sufficient for energy and protein needs or the existence of health problems and a lack of certain nutrients and is allowed to drag on during pregnancy can cause pregnant women to lack chronic energy (Kasim et al., 2019). When pregnant women experience chronic energy deficiency events, it will cause greater danger (Kedir et al., 2016).

Nahar et al. (2009) conducted a study on the effects of giving energy supplementation to pregnant women in Bangladesh showing that supplementation in pregnant women with chronic energy deficiency, increased body weight was more significant than pregnant women with normal nutritional status. This shows that, increasing energy intake will greatly affect the body weight and nutritional status of pregnant women will be optimal.

One of the impacts that can be experienced by pregnant women if protein intake is lacking is that they will experience chronic energy deficiency which is seen based on measurements of upper arm circumference (MUAC) (Irawan et al., 2014). MUAC measurement is an alternative that is easier than body mass index (BMI) in identifying chronic energy deficiency events and more importantly, MUAC is only used for initial screening in pregnant women and cannot be used as a tool for monitoring nutritional status during pregnancy (Chakraborty et al., 2011).

Another factor that affects the incidence of chronic energy deficiency in preg- nant women is education. The higher the level of education, the easier it is for pregnant women to receive information about nutrition so that the mother's knowledge about the nutrition of pregnant women will be better (Ervinawati et al., 2019). Education also affects income. If higher education is the opportunity to get sufficient income, they can live better and healthier (Department of Nutrition and Public Health, University of Indonesia, 2014).

The level of knowledge is directly related to the age of the mother. Pregnant women who are less than 20 years old are biologically still not stable emotions so that it is easy to experience emotional changes that result in adequate nutrition and socioeconomic fulfillment, pregnant women at a young age will easily experience chronic energy shortages (Abraham et al., 2015). In pregnant women with low socioeconomic status do not have the ability to buy quality or quantity of food compared to people of high socioeconomic status (Noviyanti et al., 2019).

Other factors related to chronic energy deficiency in pregnant women are seasonal or chronic food unavailability at the household level. The availability of food is the ability of the family to fulfill the food needs of all family members in sufficient quantities, both in quantity and nutritional quality (Petrika et al., 2016).

Food availability is very dependent on family purchasing power. If family purchasing power decreases, food availability will also decrease as well and vice versa. If the food availability in the household decreases, the consumption of food and nutrient intake per family member is reduced, causing nutritional problems (Petrika et al., 2016).

Basic Health Research (Riskesdas), in 2018, reported the prevalence of pregnant women experiencing chronic energy defi- 
Journal of Maternal and Child Health (2019), 4(6): 474-485

https://doi.org/10.26911/thejmch.2019.04.06.08

ciency of 20.40\%. Profile of the Yogyakarta Special Region Health Office reported an incidence of protein energy shortages of $10.39 \%$ and an increase in 2017 to $10.70 \%$. In 2018 , the prevalence of chronic energy deficiency is $9.11 \%$. The prevalence of chronic energy deficiency in pregnant women in Gunungkidul Regency in 2014 was $16.38 \%$, a decrease in the incidence of chronic energy shortages in 2016 was $15.83 \%$. In 2016, there was a decline to $15.68 \%$. In 2017, the prevalence of chronic energy deficiency is $15.34 \%$ (Gunungkidul District Health Office, 2017).

The prevalence of chronic energy shortages in Gunungkidul from year to year has not changed much in a better direction. Although the incidence of chronic energy deficiency in Gunungkidul Regency shows a lower number than the national target (less than 20\%), the chronic energy shortage problem needs to be considered because chronic energy shortages can risk the occurrence of low birth weight (LBW) so that future impacts can increase infant mortality. Low birth weight babies in Gunungkidul Regency are the highest cause of infant mortality.

\section{SUBJECTS AND METHOD}

\section{Study Design}

This study used a case control design. The study was conducted in 25 health centers in Gunungkidul Regency in April-May 2019.

\section{Population and samples}

The population were all pregnant women in Gunungkidul District health center in AprilMay 2019. The sampling used was a fixed disease sampling for sampling in pregnant women and cluster sampling for sample pregnancies at the public health center. The sample used by 200 pregnant women came from 8 pregnant women in each level 2 unit (public health center).

\section{Study Variables}

The dependent variable was chronic energy deficiency. The independent variables were food intake, education level, occupation, knowledge, family income, age, parity, utilization of ANC services, and food availability, and level 2 is a health center.

\section{Operational Definition of Variables} Intake consumes energy and protein sources. Eating food sources of energy and protein is the amount of energy and protein from food consumed by pregnant women daily from morning to night, including the type and amount. The measurement scale used was a continuous scale, for the needs of data analysis, it is converted into a dichotomy.

Educational background. The level of education is the education status of the highest school graduation achieved by pregnant women based on the ownership of the last diploma. The measurement scale used was a categorical scale.

Occupation. Occupation is the status of work which is an activity carried out in the home or outside the home which is used as income or making money to fulfill their daily needs. The measurement scale used was a categorical scale.

Knowledge. Knowledge is the mother's knowledge about the nutrition of pregnant women obtained from the answers to the questionnaire, if the correct answer is worth one if the answer is wrong then the value is zero. The measurement scale used was a continuous scale, for the needs of data analysis, it was converted into a dichotomy.

Family Income. Family income is the total amount of family income derived from the income of the head of the family and income of pregnant women, both from full time and part time job in one month and expressed in the value of money or rupiah. The measurement scale requires continous 
scale, for the needs of data analysis, it was converted into a dichotomy.

Age. Age is the age at the time of pregnancy now which is calculated based on the date of birth of pregnant women. The measurement scale was a continuous scale, and for the needs of data analysis, the data was converted into a dichotomy.

Parity. Parity is the number of childbirths that have been experienced by pregnant women both giving birth to living and dead children and influencing the number of family members. The measurement scale was continuous scale, and for data analysis needs, the data was changed to dichotomy.

Utilization of ANC services. Utilization of ANC services is the number of times the subject of research comes to health services both government and private to carry out prenatal checks conducted by health personnel. The measurement scale was continuous scale, and for data analysis needs, the data was changed to dichotomy.

Food availability. The food availability is the food condition of the family of pregnant women available in the last three months. The measurement scale was continuous scale, for the needs of data analysis, the data was converted into a dichotomy.

Chronic energy deficiency. Chronic energy deficiency is a condition in which pregnant women suffer from chronic food shortages or experience chronic energy deficiency which results in health problems in pregnant women which are characterized by results of measurements of upper arm circumference (MUAC) of less than 23.5 $\mathrm{cm}$. The measurement scale is continuous scale, and for data analysis needs, the data is changed to dichotomy.

\section{Study Instruments}

The data collection technique was done by using primary data and secondary data. Primary data was obtained using a questionnaire. The secondary data was obtained from the Gunung Kidul District Health Office in the form of data on the number of pregnant women in Gunungkidul Regency.

\section{Data Analysis}

Univariate analysis was performed to see the frequency distribution and sample characteristics. Meanwhile, bivariate analysis was performed using the chi-square test and calculation of odds ratios (OR) to analyze the relationship between chronic energy shortages and independent variables. Multivariate analysis was performed using multilevel multiple logistic regression analysis. The contextual influence of the public health centers on chronic energy deficiency was indicated by intra class correlation (ICC) values.

\section{Research Ethics}

Research ethics include informed consent, anonymity, confidentiality and ethical clearance. Ethical clearance in this study was carried out at Dr. Moewardi Surakarta and declared worthy of ethics based on decree number: 456 / IV / HERC / 2019.

\section{RESULTS \\ 1. Sample characteristics}

The samples in this study were 200 pregnant women. The frequency distribution characteristics of the samples are described in table 1.

Table 1 shows that 50 pregnant women with chronic energy deficiency (25\%), 143 of them with high food intake (71.5\%), 144 with higher education levels (72.0\%), 148 of working mothers (74.0\%), 140 subjects (70.0\%) of them with enough knowledge, family income $\geq$ regional minimum wage (UMR) of 137 subjects (68.5\%), age at risk of 142 subjects (71.0\%), parity $\geq$ 2 amounting to 139 subjects (69.5\%), utilization high ANC services amounting to 139 subjects (69.5\%), and guaranteed food 
Journal of Maternal and Child Health (2019), 4(6): 474-485

https://doi.org/10.26911/thejmch.2019.04.06.08

availability amounting to 153 subjects (76.5\%).

Table 1. Samples Characteristics

\begin{tabular}{|c|c|c|}
\hline Variable & $\mathbf{n}$ & $\%$ \\
\hline \multicolumn{3}{|l|}{ Chronic energy deficiency } \\
\hline MUAC $<23.5 \mathrm{~cm}$ & 50 & 25.0 \\
\hline MUAC $\geq 23.5 \mathrm{~cm}$ & 150 & 75.0 \\
\hline \multicolumn{3}{|l|}{ Food intake } \\
\hline Low $($ NAR $<70 \%)$ & 57 & 28.5 \\
\hline High (NAR $\geq 70 \%)$ & 143 & 71.5 \\
\hline \multicolumn{3}{|l|}{ Educational background } \\
\hline Low ( $\leq$ Junior high school) & 56 & 28.0 \\
\hline High ( $\geq$ Junior high school) & 144 & 72.0 \\
\hline \multicolumn{3}{|l|}{ Occupation } \\
\hline Working & 148 & 74.0 \\
\hline Not working & 52 & 26.0 \\
\hline \multicolumn{3}{|l|}{ Knowledge } \\
\hline Adequate & 60 & 30.0 \\
\hline Inadequate & 140 & 70.0 \\
\hline \multicolumn{3}{|l|}{ Family Income } \\
\hline$<$ Minimum wage $(<\operatorname{Rp} 1,571,000)$ & 63 & 31.5 \\
\hline$\geq$ Minimum wage $(\geq \operatorname{Rp} 1,571,000)$ & 137 & 68.5 \\
\hline \multicolumn{3}{|l|}{ Age } \\
\hline$<20$ years or $>35$ years & 58 & 29.0 \\
\hline$\geq 20$ years to 35 years & 142 & 71.0 \\
\hline \multicolumn{3}{|l|}{ Parity } \\
\hline$<2$ children & 61 & 30.5 \\
\hline$\geq 2$ children & 139 & 69.5 \\
\hline \multicolumn{3}{|l|}{ Utilization of ANC services } \\
\hline Low (TM I and II $<1$ time or TM III $<2$ time) & 61 & 30.5 \\
\hline High (TM I and II $\geq 1$ time or TM III $\geq 2$ time) & 139 & 69.5 \\
\hline \multicolumn{3}{|l|}{ Food availability } \\
\hline Poor & 47 & $23 \cdot 5$ \\
\hline Good & 153 & 76.5 \\
\hline
\end{tabular}

\section{Bivariate Analysis}

Bivariate analysis was conducted to analyze the relationship of the dependent variable (chronic energy deficiency) with the independent variables (energy and protein intake, education level, occupation, knowledge, family income, age, parity, utilization of ANC services, and food availability). The results of bivariate analysis can be seen in table 2. The results of bivariate analysis showed that there was a significant relationship between chronic energy deficiency and energy and protein food intake (OR= 6.01; $\mathrm{p}<0.001)$, education level $(\mathrm{OR}=7.15$; $\mathrm{p}<0.001)$, employment $(\mathrm{OR}=5.87 ; \mathrm{p}$ $<0.001)$, knowledge $(\mathrm{OR}=3.69 ; \mathrm{p}<0.001)$, family income $(\mathrm{OR}=7.76 ; \mathrm{p}<0.001)$, age $(\mathrm{OR}=3.99 ; \mathrm{p}<0.001)$, reality $(\mathrm{OR}=4.00$; $\mathrm{p}<0.001)$, utilization of ANC services (OR= 3.59; $\mathrm{p}<0.001$ ), and food availability (OR= 4.47; $\mathrm{p}<0.001$ ).

\section{Multilevel Analysis}

Multilevel multiple logistic regression analysis was conducted to analyze the effect of independent variables (energy and protein intake, education level, occupation, knowledge, family income, age, parity, utilization of ANC services, and food availability) with chronic energy deficiency dependent variables.

The results of multilevel multiple logistic regression showed that energy and 
protein meal intake $(\mathrm{b}=-2.74 ; 95 \% \mathrm{CI}=-$ 7.74 to $-1.28 ; \mathrm{p}=0.006)$, education level $(b=-2.16 ; 95 \% \mathrm{CI}=-4.54$ to $-0.22 ; \mathrm{p}=$ o.030), occupation ( $\mathrm{b}=-2.75 ; 95 \% \mathrm{CI}=$ 9.48 to $-1.59 ; \mathrm{p}=0.006)$, knowledge $(\mathrm{b}=-$ 2.32; $95 \% \mathrm{CI}=-6.27$ to $-0.52 ; \mathrm{p}=-0,020)$, family income $(b=-2.38$; CI $95 \%-6.27$ to $0.60 ; \mathrm{p}=0.017$, age $(\mathrm{b}=-2.17 ; 95 \% \mathrm{CI}=-$

Table 2. Bivariate Analysis
5.16 to $-0.26 ; \mathrm{p}=0.030)$, parity $(\mathrm{b}=-2.57$; 95\% $\mathrm{CI}=-8.42$ to $-1.13 ; \mathrm{p}=0.010$ ), utilizetion of ANC $(b=-2.72 ; 95 \% \mathrm{CI}=-9.20$ to $1.49 ; \mathrm{p}=0.007)$, and food availability $(\mathrm{b}=-$ 2.54; 95\% CI $=-7.63$ to $-0.98 ; \mathrm{p}=0.011$ ) had a statistically significant effect on chronic energy deficiency in pregnant women.

\begin{tabular}{|c|c|c|c|c|c|c|}
\hline \multirow{3}{*}{ Variable group } & \multicolumn{4}{|c|}{ CED } & \multirow{3}{*}{$\mathbf{O R}$} & \multirow{3}{*}{$\mathbf{p}$} \\
\hline & \multicolumn{2}{|c|}{ Yes } & \multicolumn{2}{|c|}{ No } & & \\
\hline & $\mathbf{n}$ & $\%$ & $\mathbf{n}$ & $\%$ & & \\
\hline \multicolumn{7}{|l|}{ Food Intake } \\
\hline Low $(\mathrm{AKG}<70 \%)$ & 29 & 58.0 & 21 & 42.0 & 6.01 & $<0.001$ \\
\hline High (AKG $\geq 70 \%)$ & 28 & 18.6 & 122 & 81.4 & & \\
\hline \multicolumn{7}{|l|}{ Educational background } \\
\hline Low ( $\leq \mathrm{JHS})$ & 30 & 60.0 & 20 & 40.0 & 7.15 & $<0.001$ \\
\hline $\operatorname{High}(\geq \mathrm{SHS})$ & 26 & $17 \cdot 3$ & 124 & 82.7 & & \\
\hline \multicolumn{7}{|l|}{ Occupation } \\
\hline Working & 27 & 54.0 & 23 & 46.0 & 5.87 & $<0.001$ \\
\hline Not working & 25 & 16.6 & 125 & 83.4 & & \\
\hline \multicolumn{7}{|l|}{ Education } \\
\hline Low & 26 & 52.0 & 24 & 48.0 & 3.69 & $<0.001$ \\
\hline High & 34 & 22.6 & 116 & 77.4 & & \\
\hline \multicolumn{7}{|l|}{ Family Income } \\
\hline$<$ minimum wage $(<\operatorname{Rp} 1,571,000)$ & 33 & 66.0 & 17 & 34.0 & 7.76 & $<0.001$ \\
\hline$\geq$ minimum wage $(\geq \operatorname{Rp} 1,571,000)$ & 30 & 20.0 & 120 & 80.0 & & \\
\hline \multicolumn{7}{|l|}{ Age } \\
\hline Risky $(<20$ years or > 35 years $)$ & 26 & 52.0 & 24 & 48.0 & 3.99 & $<0.001$ \\
\hline Not risky ( $\geq 20-35$ years) & 32 & 21.3 & 118 & 78.7 & & \\
\hline \multicolumn{7}{|l|}{ Parity } \\
\hline$<2$ children & 23 & 46.0 & 27 & 54.0 & 4.00 & $<0.001$ \\
\hline$\geq 2$ children & 116 & 77.4 & 34 & 22.6 & & \\
\hline \multicolumn{7}{|l|}{ Utilization of ANC services } \\
\hline Low & 26 & 52.0 & 24 & 48.0 & 3.56 & $<0.001$ \\
\hline High & 35 & 23.3 & 115 & 76.7 & & \\
\hline \multicolumn{7}{|l|}{ Food availability } \\
\hline Lacking & 23 & 46.0 & 27 & 54.0 & 4.47 & $<0.001$ \\
\hline Assured & 24 & 16.0 & 126 & 84.0 & & \\
\hline
\end{tabular}

Community health center had strong contextual effect on chronic energy deficiency with $\mathrm{ICC}=51.25 \%$. It indicates that variations in chronic energy deficiency in pregnant women as much as $51.25 \%$ are determined by variables at the puskesmas level. The ICC value in this study is greater than the benchmark 8-10\% rule of thumb, so the contextual influence of the public health center is very important to note. 
Journal of Maternal and Child Health (2019), 4(6): 474-485

https://doi.org/10.26911/thejmch.2019.04.06.08

Table 3. The results of multilevel multiple logistic regression analysis

\begin{tabular}{|c|c|c|c|c|}
\hline \multirow[b]{2}{*}{ Independent Variables } & \multirow[b]{2}{*}{$\mathbf{b}$} & \multicolumn{2}{|c|}{$95 \% \mathrm{CI}$} & \multirow[b]{2}{*}{$\mathbf{p}$} \\
\hline & & $\begin{array}{c}\text { Lower } \\
\text { Limit }\end{array}$ & $\begin{array}{c}\text { Upper } \\
\text { Limit }\end{array}$ & \\
\hline \multicolumn{5}{|l|}{ Fixed effect } \\
\hline Energy and protein intake (high) & -2.74 & -1.28 & -7.74 & 0.006 \\
\hline Educational background (>SHS) & -2.16 & -0.22 & -4.54 & 0.030 \\
\hline Occupation (working) & -2.75 & -1.59 & -9.48 & 0.006 \\
\hline Knowledge (good) & -2.32 & -0.52 & -6.27 & 0.020 \\
\hline Family Income ( $\geq$ Rp $1,571,000)$ & -2.38 & -0.60 & -6.27 & 0.017 \\
\hline Age $(\geq 20-35$ years $)$ & -2.17 & -0.26 & -5.16 & 0.030 \\
\hline Parity (>2 children) & -2.57 & -1.13 & -8.42 & 0.010 \\
\hline Utilization of ANC services & -2.72 & -1.49 & -9.20 & 0.007 \\
\hline \multicolumn{5}{|l|}{ Food availability } \\
\hline Random effect & -2.54 & -0.98 & -7.63 & 0.011 \\
\hline \multicolumn{5}{|l|}{$\mathrm{N}$ observation $=200$} \\
\hline \multicolumn{5}{|l|}{$\mathrm{N}$ group $=25$} \\
\hline \multicolumn{5}{|l|}{ Average of the group $=8, \operatorname{Min}=8, \operatorname{Max}=8$} \\
\hline Log likelihood $=-30.63, p=0.029 . \quad I C C=51.25 \%$ & & & & \\
\hline
\end{tabular}

\section{DISCUSSION}

1. The effect of food intake on CED

The results of this study indicated that the higher the food intake of pregnant women, the lower the risk of chronic energy deficiency in pregnant women. The results of this study indicate that there was a relationship between chronic energy deficiency and was statistically significant food intake.

Women will experience malnutrition based on their intake. Pregnant women with poor food intake because pregnant women pay less attention to fulfilling their own food will have an impact on the nutritional state of pregnant women (Helliyana et al., 2019). Mothers with poor food intake can be indicated that the mother is not fulfilled her nutritional needs so she has the opportunity to have a lack of nutritional status. If this habit lasts long, pregnant women will be at risk of developing CED (Legesse et al., 2019).

\section{The effect of education level on CED}

The results of this study indicate that the higher the education of pregnant women, the lower the risk of chronic energy deficiency in pregnant women. The results of this study indicate that there was a statistically significant relationship between the chronic energy deficiency and education.

The results of this study are in line with Ervinawati et al. (2019) stating that there was a statistically significant relationship between the level of education of the mother and the incidence of chronic energy deficiency. A person's level of education will also affect his social life. The higher the education of a person, the more information obtained. The level of education will determine whether or not someone is easy to absorb and understand nutrition and health knowledge (Mahirawati, 2014).

The education status of pregnant women also greatly influences the quality and quantity of food consumption, because with higher education it is expected that knowledge or information about the nutrients they possess will be better. It is because nutritional problems often arise due to ignorance or lack of information about nutrition (Priyanka et al., 2014; Daba et al., 2013).

\section{The effect of occupation on CED}

The results of this study indicate that pregnant women who work might reduce 
the risk of chronic energy deficiency in pregnant women. The results of this study indicate that there was a relationship between chronic energy deficiency and was statistically significant. This study is in line with study conducted by (Mahirawati, 2014) stating that the occupation of a pregnant woman has an influence on the incidence of malnutrition. Working women had the ability to recognize family health problems. Women's knowledge of working on health problems is obtained from books, magazines, newspapers, radio, and television.

Working women had the ability to make decisions to overcome the health problems they face. Women who act as workers as well as wives and housewives generally have better health.

Working mothers have their own income so that to fulfill their nutritional needs, they do not depend on their husbands. Occupation affects the economic status. Health needs such as the fulfillment of health facilities and nutritional needs can be fulfilled if the family has economic capacity (Wong et al., 2018).

\section{The effect of knowledge on the CED}

The results of this study indicate that the higher the knowledge of pregnant women, the lower the risk of chronic energy deficiency in pregnant women. The results of this study indicated that there was a relationship between chronic energy deficiency and was statistically significant maternal knowledge.

The results of this study are in line with the study of Daba et al. (2013) which states that there is a relationship between knowledge and the incidence of chronic energy shortages. Malnutrition can occur due to a lack of knowledge that a mother has. Malnutrition can occur due to ignorance. Someone who has more knowledge about the nutritional status needed during pregnancy will be more careful in determining the type of food to be consumed. The level of knowledge of a person's nutrition will affect attitudes and behavior in food selection.

Pregnant women who have knowledge would be more careful in choosing foods to eat. Knowledge is obtained not only from formal education, but can be obtained through health personnel, printed media, and electronic media. Pregnant women who have knowledge when experiencing health problems will find out more about how to deal with the problems they are experiencing (Wong et al., 2018).

Pregnant women who work will recognize their family's health problems. Pregnant women who work have the ability to make decisions to overcome health problems faced. Therefore women who act as workers as well as wives and housewives generally have better health (Ernawati, 2018).

\section{The effect of family income on CED}

The results of this study indicate that the higher the income of pregnant women, the lower the risk of chronic energy deficiency in pregnant women. The results of this study indicate that there was a relationship between chronic energy shortages and was statistically significant income.

Noviyanti et al. (2019) states that income affect the incidence of chronic energy shortages. Family income reflects the ability of the community in terms of the economy in fulfilling their needs including health needs and fulfillment of nutrients. The level of income determines what food patterns are purchased, the higher the income, the more spending for shopping. This concerns the fulfillment of needs in the family, especially the fulfillment of the need for foods that have adequate amounts of nutritional value (Wong et al., 2018). 
Journal of Maternal and Child Health (2019), 4(6): 474-485

https://doi.org/10.26911/thejmch.2019.04.06.08

Income is the main thing that affects the quality of the menu to be consumed. Low income causes low purchasing power too, so that it is unable to buy food in the amount needed, this condition is very dangerous for family health and ultimately can have a negative impact on the nutritional state of pregnant women (Daba et al., 2013).

\section{The effect of age on CED}

The results of this study indicate that the higher the age of pregnant women, the lower the risk of chronic energy deficiency in pregnant women. The results of this study indicate that there was a relationship between chronic energy deficiency and age statistically significant.

Pregnant women younger than 20 years had a higher risk of chronic energy shortages, even pregnant women who are too young can increase their risk of chronic energy deficiency. Age is one of the important factors in the process of pregnancy to childbirth, because pregnancy in young mothers causes food competition between the fetus and the mother who is still in its infancy (Mahirawati, 2014).

\section{The effect of parity on CED}

The results of this study indicate that the fewer parity of pregnant women, the lower the risk of chronic energy deficiency in pregnant women. The results of this study indicate that there was a relationship between chronic energy deficiency and statistically significant parity.

Study results of Ervinawati et al. (2019) show that there is a causal relationship between parity and that which occurs in chronic energy shortages with pregnant women. Families with large numbers of children and close birth spans will cause problems. The income in the family is mediocre and has a large number of family members so that the distribution and adequacy of food in the family is lacking so that it can cause malnutrition (Bharati et al., 2019).

The number of family members would influence the level of food consumption, namely the amount and distribution of food in the household. The smaller the number of family members, the ability to provide diverse food is also greater because it does not require a large amount of money to buy a variety of foods compared to the number of large family members.However, the number of large family members without being balanced with uneven food distribution will cause these pregnant women to experience chronic energy shortages (Ekowati, 2017).

\section{The effect of the use of ANC ser- vices on CED}

The results of this study indicate that the more frequent pregnant women do antenatal care, the lower the risk of chronic energy deficiency in pregnant women. The results of this study indicate that there was a relationship between chronic energy deficiency and was statistically significant utilization of ANC services.

This is in line with the study of Ghosh et al. (2015) stating that there is an influence between the condition of pregnant women and the utilization of ANC services. When a person is in an unhealthy or disturbed condition, then they will be more aware of using health services sufficiently so that their conditions are good. Pregnant women who experience complaints or complications during pregnancy, they will be more vigilant and more careful in undergoing each process of peace.

Pregnant women who use ANC services will have more knowledge than health workers (Purbaningrum et al., 2019). If pregnant women have a complaint, pregnant women can ask when doing ANC, especially complaints about complications of nutritional intake during pregnancy. 


\section{The effect of food availability on CED}

The results of this study indicated that there was a relationship between chronic energy deficiency and it was statistically significant.

The results of this study are in line with the study of Legesse (2019) which states that there is a relationship between the level of energy intake and food availability with the risk of chronic energy deficiency in pregnant women. This study was conducted in the post-harvest season while the study conducted in Gondar was in the season before harvest. Seasonal differences affect food prices, accessibility, and availability of various foods in the community. Food availability can limit household access to adequate quantity and quality of food which can result in unhealthy nutritional outcomes among family members.

\section{The effect of the level of public health centers on CED}

The results of this study indicate that community health center had strong contextual effect on chronic energy deficiency with $\mathrm{ICC}=51.25 \%$.

The public health center is the leading health care unit directly under the coordination and guidance of the central government. PHC provides integrated services including $\mathrm{MCH}$, family planning, immunization, nutrition, and treatment of diarrhea. One of them is providing services, monitoring the nutritional status of mothers during pregnancy, to prevent the occurrence of health problems that can cause death to both mothers and infants (Bappenas, 2018).

\section{AUTHORS CONTRIBUTION}

Nur Cahya Rachmawati is the main author who played a role in collecting and processing the data. Yulia Lanti Retno Dewi examined the conceptual framework and methodology. Vitri Widyaningsih examined the manuscript.

\section{FUNDING AND SPONSORSHIP}

This study is self-funded.

\section{CONFLICT OF INTEREST}

There is no conflict of interest.

\section{ACKNOWLEDGMENT}

We would like to thank the community health center for helping us with the study and the participating pregnant women who were willing to be the subjects.

\section{REFERENCE}

Abraham S, Miruts G, Shumye A (2015). Magnitude of chronic energy deficiency and its associated factors among women of reproductive age in the Kunama population, Tigray, Ethiopia, in 2014. BMC Nutrition, 1(2): 1-9. doi: 10.1186/s40795-0150005-y.

Almatsier S (2009). Prinsip dasar ilmu gizi (Basic principles of nutrition science). Jakarta: Gramedia Pustaka Utama.

Arisman (2010). Buku ajar ilmu gizi: gizi dalam daur kehidupan (Nutrition science textbooks: nutrition in the life cycle): Jakarta: EGC.

Bappenas (2018). Penguatan pelayanan kesehatan dasar di puskesmas (Strengthening basic health services at health centers). Jakarta: Direktorat Kesehatan dan Gizi Masyarakat Kedeputian Pembangunan Manusia, Masyarakat, dan Kebudayaan Kementerian PPN/Bappenas. Retrieved from: https://www.bappenas.go.id/id/profil-bappenas/unit-kerja/deputisdm/dit-kgm/contents-direktorat-kesehatan-dan-gizi-masyarakat/penguatan-pelayanan-kesehatan-dasar-di- 
Journal of Maternal and Child Health (2019), 4(6): 474-485

https://doi.org/10.26911/thejmch.2019.04.06.08

puskesmas/

Bharati S, Manoranjan P, Soumendu S (2019). Malnutrition and anemia among adult women in India. J. Biosoc. Sci., 10: 1-11. doi: doi:10.1017/So02193201800041X.

Chakraborty R, Bose K, Koziel S (2011). Use of mid-upper arm circumference in determining undernutrition and illness in rural adult Oraon men of Gumla District, Jharkhand, India. Rural Remote Health, 11(3): 1754. Retrieved from: www.rrh.org.au/journal/article/1754

Daba G, Beyene F, Garoma W, Fekadu H (2013). Assessment of nutritional practices of pregnant mothers on maternal nutrition and associated factors in Guto Gida Woreda, East Wollega Zone, Ethiopia. STAR Journal, 4(1): 1000130. doi: 10.4172/21610509.1000130.

Department of Nutrition and Public Health, University of Indonesia (2014). Gizi dan kesehatan masyarakat (Nutrition and public health). Jakarta: Rajawali Pers.

Gunungkidul District Health Office (2017). Profil kesehatan dinas kesehatan Kabupaten Gunungkidul (Health profile of the Gunungkidul District health office). Retrieved from: https://dinkes.gunungkidulkab.go.id/.

Ekowati D, Seri AL, Trisna W (2017). High parity and chronic energy deficiency increase risk for low birth weight in Situbondo District. Public Health and Preventive Medicine Archive, 5(1): 3540. doi: 10.24843/phpma.2017.vo5.io1.po6.

Ernawati A (2018). Hubungan usia dan status pekerjaan ibu dengan kejadian kurang energi kronis pada ibu hamil (The relationship between maternal age and employment status with chro- nic lack of energy in pregnant women). Jurnal Litbang: Media Informasi Penelitian, Pengembangan dan IPTEK, 13(1): 27-28. doi: 10.33658/jl.v14i1.106.

Ervinawati E, Wirda A, Nurlisis N (2019). Determinant of chronic energy manutrition (CEM) in pregnant woman at Lubuk Muda Public Health Center. Jurnal Kesehatan Komunitas, 4(3): 120-125. doi: 10.25311/keskom.vol4.iss3.289.

Ghosh JS, Devasenapathy N, Singh A, Shankar A, Zodpey S (2015). Ante natal care (ANC) utilization, dietary practices and nutritional outcomes in pregnant and recently delivered women in urban slums of Delhi, India: an exploratory cross-sectional study. J Matern Child Health, 12:12-20. doi: 10.1186/s12978-015-0008-9.

Helliyana H, Aritonang EY, Sanusi SR (2019). The associations between maternal education, chronic energy deficit, and anemia in pregnant women: an evidence from Lhokseumawe, Indonesia. J Matern Child Health, 4(3): 212-221. doi: 10.26911/thejmch.2019.04.05.02.

Irawa A, Abdul RT, Devinta V (2014) Hubungan asupan energi dan protein dengan status IMT dan LILA ibu prakonsepsional di Kecamatan Ujung Tanah dan Biringkanaya Kota Makassar (Relationship between energy and protein intake with BMI and LILA status of pre-consecutive mothers in Ujung Tanah and Biringkanaya Sub-Districts, Makassar City). Artikel Penelitian Program Studi Ilmu Gizi Fakultas Kesehatan Masyarakat Universitas Hasanuddin.

Kasim F, Sirajuddin S, Amiruddin R (2019). The effect of moringa oleifera leaf biscuit on the increase of body weight 
and upper arm circumference for chronic energy deficiency among pregnant women in Bontoramba District Jeneponto Regency. Indian Journal of Public Health Research and Development, 10(4): 1018. doi: 10.5958/0976-5506.2019.00842.8.

Kedir H, Berhane Y, Worku A (2016). Magnitude and determinants of malnutrition among pregnant women in eastern Ethiopia: evidence from rural, community-based setting. Maternal and Child Nutrition, 12(1): 51-63. doi: $10.1111 / \mathrm{mcn} .12136$.

Legesse M, Abebe Z, Woldie H (2019). Chronic energy deficiency and associated factors among older population in Ethiopia: a community based study. Plos One, 14(4): eo214861. doi: 10.1371/journal.pone.0214861.

Mahirawati VK (2014). Related factors of chronic energy deficiency at pregnant woman in Kamoning and Tambelangan Sub District, Sampang District, West Java. Buletin Penelitian Sistem Kesehatan, 17(2): 193-202. doi: 10.22435/bpsk.v17i2 Apr.3609

Maryani S, Respati SH, Astirin, OP (2017). Association between pregnant woman class and pregnancy complication in Tegal District, Central Java. J Matern Child Health, 1(4): 214-219. doi: 10.26911/thejmch.2016.01.04.02.

Nahar S, Mascie CGN, Begum HA (2009). Impact of targeted food supplementation on pregnancy weight gain and birth weight in rural Bangladesh: an assessment of the Bangladesh integrated nutrition Program (BINP). Public Health Nutr., 12(8): 1205-1211. doi: 10.1017/S1368980008003765.

Noviyanti B, Harry CS, Eka SPH, Hendrika AS, Endy J (2019). The Relationship between social economic levels and anemia events in pregnant women in
Glugur Darat Health Center. J Matern Child Health, 4(6): 48-56. doi: https://doi.org/10.26911/thejmch.2019.04.06 .05 .

Petrika Y, Hadi H, Nurdiati DS (2016). Tingkat asupan energi dan ketersediaan pangan berhubungan dengan risiko kekurangan energi kronik (KEK) pada ibu hamil (The level of energy intake and food availability is associated with the risk of chronic energy deficiency (SEZ) in pregnant women). Jurnal Gizi dan Dietetik

Indonesia (Indonesian Journal of Nutrition and Dietetics), 2(3): 140-149. doi: 10.21927/ijnd.2014.

Priyanka D, Mahajan SL, Gill KP (2014). Prevalence of chronic energy deficiency and socio demographic profile of women in slums of Amritsar city, Punjab, India. International Journal of Research in Health Sciences, 2(2): 527-532.

Purbaningrum SA, Qadrijati I, Adriani RB, Prasetya $H$ (2019). Multilevel analysis on the determinants of antenatal care visit at community health center in Madiun, East Java. J Matern Child Health, 4(3): 180-189. doi: https://doi.org/10.26911/thejmch.2019.04.03.05 .

Wong JL, Lim PY, Soon LK, Lim ZX (2018). Knowledge of nutrition during pregnancy and associated factors among antenatal mothers. International Journal of Public Health and Clinical Sciences, 5(1): 118-128. Retrieved from: http://publichealthmy.org/ejournal/ojs2/index.php/ijphcs/article /view/531. 